\title{
Hubungan Bimbingan Kelompok dengan Motivasi Belajar Siswa SMP Negeri 5 Rambah Kabupaten Rokan Hulu Provinsi Riau
}

\author{
Hasbi * \\ * SMP Negeri 5 Rambah
}

\begin{tabular}{l}
\hline INFO ARTIKEL \\
\hline Riwayat Artikel: \\
Diterima: 6 Oktober 2018 \\
Disetujui: 10 Desember 2018
\end{tabular}

Kata kunci:
Bimbingan Kelompok
Motivasi Belajar
Hubungan

\section{Alamat Korespondensi:}

Hasbi,

SMP Negeri 5 Rambah

Jl. Ronggowarsito I No. 15 Pekanbaru

E-mail: hasbi@gmail.com

\begin{abstract}
ABSTRAK
Abstract: In writing this article the writer chooses research with the title of Relationship Guidance Group with Learning Motivation for Students of SMP Negeri 5 Rambah, Rokan Hulu Regency, Riau Province. This article aims to describe the learning motivation of students in SMP Negeri 5 Rambah Hilir, Rokan Hulu Regency, Riau Province; describe the implementation of guidance for groups of SMP Negeri 5 Rambah Hilir, Rokan Hulu Regency, Riau Province; and know whether or not there is a relationship between students' learning motivation with the guidance of the group of SMP Negeri 5 Rambah Hilir, Rokan Hulu Regency, Riau Province. This article discusses two variables, namely group guidance and learning motivation. The population in this study were students of SMP Negeri 3 Rambah Hilir Academic Year 2013/2014 which amounted to 82 students consisting of three classes. The sample that will be used in this study is SMP Negeri 3 students which are Downstream in 2013/2014 Academic Year with a total of 82 students. The sampling technique used by researchers is a sample consideration. What is meant by sample consideration is in taking the sample, researchers take samples based on certain considerations. This sampling is based on consideration at the highest class average. So the research made the VIIA class as a research sample as many as 29 students. The type of research used in this study is expost facto research or referred to after after the fact. Data collection techniques used are documentation, observation, and questionnaire.

Based on the calculation results obtained that the significance value is 0,000 which is smaller than the value of $\mathrm{a}=0.05$ and the calculated value is $0.599^{* *}$ in the "moderate" category. The price of the coefficient is then tested for significance by comparing the table for $\mathrm{n}=80$ at the level of $5 \%$, then table $=0.220$, where the value of $r$ count $>r$ table $(0.599>0.220)$ and the significance value obtained is less than 0.05 . Thus, $\mathrm{Ha}$ is accepted, that is, there is a relationship between group guidance services and Learning Motivation for class VIII students of SMP Negeri 5 Rambah Hilir, Rokan Hulu Regency, Riau Province. While the contribution of group guidance services in improving student learning motivation is $35.88 \%$.
\end{abstract}

\section{LATAR BELAKANG}

Kegiatan belajar mengajar di kelas bukanlah hanya sebuah kegiatan transfer ilmu semata, tapi lebih jauh lagi dalam hal penyiapan dan pembentukan generasi yang lebih kompenten pada bidang yang pilihnya. Tentunya kegiatan belajar mengajar yang dilakukan dikelas tidaklah semudah dalam sinetron yang "tiba-tiba" menjadi pintar tanpa upaya maksimal baik dari guru, siswa, sekolah dan aspek lainnya yang mempengaruhi pendidikan 
108 Instructional Development Journal (IDJ), Vol. 1, No. 2, Desember 2018, Hal. 107-112

itu sendiri. Dibutuhkan dukungan dari semua aspek yang menjadi faktor penentu keberhasilan kegiatan belajar mengajar di sekolah dan salah satunya adalah tingkat kemampuan guru atau pembimbing dalam menemukan dan melayani perbedaan individu siswa yang mengalami kesulitan belajar.

Guru adalah komponen dari sekolah yang berperan penting dalam membantu siswa untuk mencapai hasil belajar yang optimal. Jadi seorang guru dituntut mempunyai pengetahuan keterampilan, dan sikap yang profesional dalam membelajarkan siswa-siswanya (Max Darsono dkk, 2001: 1). Dalam upaya meningkatkan pelayanan pendidikan terhadap siswa yang masing-masing individunya berbeda. Karena dalam proses belajar sehari-hari di sekolah, tentunya tidak jarang menemui anak-anak yang mengalami kesulitan dalam belajar. Anakanak yang sepertinya sulit sekali menerima materi pelajaran, baik pelajaran membaca, menulis, serta berhitung. Hal ini terkadang membuat guru menjadi frustasi memikirkan bagaimana menghadapi anak-anak seperti ini. Demikian juga para orang tua yang memiliki anak-anak yang memiliki kesulitan dalam belajar.

Dalam keseluruhan sistem pendidikan, tujuan pendidikan merupakan salah satu komponen pendidikan yang penting, karena akan memberikan arah proses kegiatan pendidikan. Segenap kegiatan pendidikan atau kegiatan pembelajaran diarahkan guna mencapai tujuan pembelajaran. Siswa yang dapat mencapai target tujuantujuan tersebut dapat dianggap sebagai siswa yang berhasil. Sedangkan apabila siswa tidak mampu mencapai tujuan-tujuan tersebut dapat dikatakan mengalami kesulitan belajar. Untuk menandai mereka yang mendapat hambatan pencapaian tujuan pembelajaran, maka sebelum proses belajar dimulai, tujuan harus dirumuskan secara jelas dan operasional. Untuk mencapai tujuan tersebut, perlu dilakukan usaha peningkatan proses pembelajaran di setiap jenjang pendidikan. Usaha yang dapat dilakukan antara lain dengan memilih dan menerapkan model pembelajaran (strategi dan metode pembelajaran) yang sesuai, memaksimalkan pemanfaatan sumber dan bahan ajar, meningkatkan pengetahuan dan keterampilan guru dalam menyajikan materi pelajaran, dan yang paling penting adalah meningkatkan motivasi belajar siswa.

Motivasi merupakan salah satu faktor yang mempengaruhi keberhasilan belajar. Motivasi tidak hanya berpengaruh terhadap hasil belajar, tetapi juga terhadap proses belajar. Siswa yang memiliki motivasi belajar yang tinggi akan terlibat aktif dalam pembelajaran, sehingga mereka akan mencapai hasil belajar yang optimal. Demikian pula, siswa yang berhasil dalam belajar akan memiliki motivasi yang tinggi untuk terlibat dalam proses belajar berikutnya. Dalam prosesnya, guru diharapkan dapat merangsang anak didik sehingga dapat menumbuhkan motivasi dalam belajar. Karena menurut Mc. Donald : "Motivasi adalah perubahan energi dalam diri seseorang yang ditandai dengan munculnya "feeling" dan didahului dengan tanggapan terhadap tujuan (Sardiman, 2004: 73)."

Berdasarkan hasil wawancara peneliti dengan salah seorang guru di SMP Negeri 5 Rambah Hilir diketahui bahwa pihak sekolah khususnya guru di sekolah tersebut telah berusaha meningkatkan motivasi belajar siswanya. Namun, dari berbagai usaha yang telah dilakukan tersebut, motivasi belajar siswa masih belum mengalami peningkatan yang berarti. Hal tersebut dapat dilihat dari gejala-gejala sebagai berikut: 1) Sebagian besar siswa lebih tertarik bercanda dengan teman-temannya saat pembelajaran berlangsung; 2) Sebagian besar siswa cenderung diam dan malas bertanya dalam pembelajaran. Hal tersebut terlihat dari sedikitnya siswa yang bertanya ketika diberi kesempatan untuk bertanya; 3) Sebagian besar siswa tidak mengerjakan latihan yang diberikan oleh guru; dan 4) Sebagian besar siswa mudah putus asa ketika menghadapi soal yang sulit. Artinya, ketika mereka tidak mampu menyelesaikan suatu soal, mereka tidak berusaha untuk bertanya kepada teman maupun gurunya; serta 5) Sebagian besar siswa tidak mengerjakan pekerjaan rumah dengan serius.

Berdasarkan gejala tersebut, guru perlu memiliki kreatifitas untuk mendorong siswanya agar tetap rajin belajar, mengerjakan tugas tepat waktu serta aktif bertanya saat guru menjelaskan materi pelajaran. Upaya yang diperlukan untuk mengatasi permasalahan motivasi belajar siswa adalah mengoptimalkan layanan bimbingan dan konseling kepada siswa. Salah satunya pemberian bantuan / bimbingan melalui layanan bimbingan kelompok. Bimbingan membantu individu untuk lebih mengembangkan diri secara optimaldengan jalan memahami diri memahami lingkungan, mengatasi hambatan guna menentukan rencana masa depan yang lebih baik. Prayitno (1995: 178) mengemukakan bahwa Bimbingan kelompok adalah Suatu kegiatan yang dilakukan oleh sekelompok orang dengan memanfaatkan dinamika kelompok. Artinya, semua peserta dalam kegiatan 
kelompok saling berinteraksi, bebas mengeluarkan pendapat, menanggapi, memberi saran, dan lain-lain sebagainya; apa yang dibicarakan itu semuanya bermanfaat untuk diri peserta yang bersangkutan sendiri dan untuk peserta lainnya.

Bimbingan kelompok merupakan salah satu kegiatan layanan yang paling banyak dipakai karena lebih efektif. Banyak orang yang mendapatkan layanan sekaligus dalam satu waktu. Layanan ini juga sesuai dengan teori belajar karena mengandung aspek sosial yaitu belajar bersama. Peserta layanan akan berbagi ide dan saling mempengaruhi untuk berkembang menjadi manusia seutuhnya. Bimbingan kelompok merupakan salah satu tehnik bimbingan yang berusaha membantu individu agar dapat mencapai perkembangannya secara optimal sesuai dengan kemampuan, bakat, minat serta nilai-nilai yang dianutnya, dan dilaksanakan dalam situasi kelompok (Tatiek Romlah, 2006 : 17). Menurut Tohirin (2007) bahwa bimbingan kelompok adalah suatu cara memberikan bantuan kepada individu atau siswa melalui kegiatan kelompok. Kelebihan dari bimbingan kelompok ini adalah dapat melatih siswa untuk hidup berkelompok dan menumbuhkan kerjasama antar siswa dalam mengatasi maslaah, melatih siswa mengemukakan pendapat dan menghargai pendapat orang lain dan dapat meningkatkan kemampuan siswa untuk dapat berkomunikasi dengan teman sebaya dan pembimbing (Winkel dan Sri Hastuti, 2004).

Di sini peranan guru pembimbing sangat berperan penting dalam pelaksanaan bimbingan kelompok. Salah satu faktor penting yang memegang peranan berhasil tidaknya suatu layanan bimbingan kelompok . dengan begitu siswa atau anak yang mengalami kesulitan dalam hal belajar akan terbantu, dan guru sebagai narasumber, karena guru mengetahui dan menguasai materi pelajaran. Maka penyelenggaraan bimbingan kelompok merupakan salah satu bentuk realisasi bimbingan dan konseling di SMP Negeri 5 Rambah Hilir. Oleh karena itu, peranan guru kelas dalam pelaksanaan BK sangat penting dalam mengefektifkan pencapaian tujuan pembelajaran yang telah dirumuskan. Di samping belajar secara individual, anak-anak pun sebaiknya juga belajar dengan sistem kelompok. Mengenai hal ini ada beberapa alas an mendasar yang dapat diajukan sebagai landasan untuk penyelengaraan bimbingan kelompok itu.

\section{METODE}

Jenis penelitian yang digunakan dalam penelitian ini adalah penelitian expost facto atau disebut dengan after the fact. Sudjana dan Ibrahim (2007: 60) mengatakan bahwa Penelitian ex post facto dimulai dengan mendeskripsikan situasi sekarang yang diasumsikan sebagai akibat dari faktor-faktor yang telah terjadi atau bereaksi sebelumnya. Penelitian ini bertujuan untuk menentukan ada tidaknya hubungan antara Variabel bebas (X) dan variable terikat (Y). Sedangakan untuk menghitung besarnya korelasi digunakannya statistik. Variabel penelitian ini dapat digambarkan sebagai berikut : 1) Variabel terikat atau dependent variable (Y) adalah motivasi belajar siswa SMP Negeri 5 Rambah Hilir Kabupaten Rokan Hulu. Sedangkan Variabel bebas atau independent variable $(\mathrm{X})$ adalah Bimbingan kelompok.

Adapun yang menjadi populasi dalam penelitian ini adalah siswa kelas VIII SMP Negeri 5 Rambah Hilir Tahun Pelajaran 2013/2014 yang berjumlah 79 siswa. Sampel yang akan digunakan dalam penelitian ini adalah siswa kelas VIII SMP Negeri 5 Rambah Hilir Tahun Pelajaran 2013/2014 sejumlah 79 siswa Untuk penelitian yang resikonya besar, tentu saja jika sampelnya besar akan lebih baik. Karena jumlah populasi kurang dari 100, maka pada penelitian ini jumlah siswa diambil dari kelas VIII SMP Negeri 5 Rambah Hilir yaitu 79 siswa yang diambil sebagai sampel dalam penelitian ini. Teknik pengumpulan data yang digunakan dalam penelitian ini adalah dokumentasi dan angket. Analisis deskriptif digunakan untuk menentukan besar rata- rata (Mean), distribusi frekuensi, dan pembuatan histogram dari variabel penelitian yang mencakup bimbingan kelompok dan motivasi belajar siswa SMP Negeri 5 Rambah Hilir Kabupaten Rokan Hulu. Analisis inferensial pada penelitian ini dilakukan dengan tujuan agar prestasi penelitian dapat dibuat kesimpulan pengujian hipotesis secara generalisasi. Untuk keperluan analisis data dalam mengetahui besar kontribusi variabel independen terhadap variabel dependen diolah dengan uji korelasi Product Moment melalui Program SPSS Versi 18.00 for windows. Sebelum melakukan analisis data ada syarat yang harus dilakukan, yaitu: uji normalitas dan uji homogenitas. 
110 Instructional Development Journal (IDJ), Vol. 1, No. 2, Desember 2018, Hal. 107-112

\section{HASIL DAN PEMBAHASAN}

Pengolahan data kajian penelitian menggunakan pengujian statistik dengan analisis korelasi Product Moment. Namun sebelum itu, peneliti melakukan uji persyaratan analisis sehingga hasilnya dapat digunakan untuk menarik kesimpulan. Uji persyaratan yang dimaksud mencakup normalitas, homogenitas dan linieritas. Hasil uji normalitas menunjukkan bahwa nilai signifikan untuk variable bimbingan kelompok sebesar 0,348 dan variable Motivasi Belajar sebesar 0,083. Nilai signifikan ini lebih besar dari taraf signifikan $\alpha=0,05$. Dengan demikian, dapat dikatakan bahwa masing-masing variable berdistribusi normal. Sedangkan uji homogenitas, varians skor bimbingan kelompok dan Motivasi Belajar siswa yang diperoleh adalah lebih besar dari taraf signifikansi $\alpha=0,05(0,912>0,05)$. Selanjutnya disimpulkan bahwa bimbingan kelompok dan Motivasi Belajar siswa adalah homogen. Hasil pengujian linieritas pengaruh setiap variable penelitian yang dilakukan menunjukkan bahwa terdapat hubungan linieritas antar variable yang satu dengan yang lainnya. Setelah memenuhi uji persyaratan tersebut, maka langkah selanjutnya adalah melakukan uji korelasi Product Moment.

Hipotesis yang diajukan dalam penelitian adalah "ada hubungan layanan bimbingan kelompok dengan Motivasi Belajar siswa kelas VIII SMP Negeri 5 Rambah Hilir Kabupaten Rokan Hulu Provinsi Riau”. Berdasarkan hipotesis penelitian tersebut, maka hipotesis nol (Ho) yang diuji adalah "tidak ada hubungan layanan bimbingan kelompok dengan Motivasi Belajar siswa kelas VIII SMP Negeri 5 Rambah Hilir Kabupaten Rokan Hulu Provinsi Riau.

Berdasarkan hasil perhitungan diperoleh bahwa nilai signifikansi adalah 0,000 yang lebih kecil dari nilai $a=0,05$ dan nilai $\mathrm{r}_{\text {hitung }}$ adalah $0,599^{* *}$ pada kategori "sedang". Harga koefisien tersebut selanjutnya diuji signifikansinya dengan membandingkan $\mathrm{r}_{\text {tabel }}$ untuk $\mathrm{n}=80$ pada taraf $5 \%$ maka $\mathrm{r}_{\text {tabel }}=0,220$, di mana nilai $\mathrm{r}_{\text {hitung }}>$ $\mathrm{r}_{\text {tabel }}(0,599>0,220)$ dan nilai signifikansi yang diperoleh lebih kecil dari 0,05. Dengan demikian, Ha diterima yaitu ada hubungan layanan bimbingan kelompok dengan Motivasi Belajar siswa kelas VIII SMP Negeri 5 Rambah Hilir Kabupaten Rokan Hulu Provinsi Riau. Sementara kontribusi layanan bimbingan kelompok dalam meningkatkan Motivasi Belajar siswa sebesar 35,88\%.

Dalam penelitian ini hipotesis kerja yang penulis laksanakan terbukti kebenarannya. Yaitu berdasarkan analisis korelasi Product Moment di atas maka dapat disimpulkan bahwa hipotesis alternatif penelitian yang berbunyi "ada hubungan layanan bimbingan kelompok dengan Motivasi Belajar siswa kelas VIII SMP Negeri 5 Rambah Hilir Kabupaten Rokan Hulu Provinsi Riau, diterima kebenarannya. Berdasarkan pengamatan penulis, adanya hubungan yang positif dan signifikan anatara bimbingan kelompok dengan Motivasi Belajar siswa disebabkan oleh beberapa faktor, diantaranya faktor bimbingan kelompok, seperti yang dinyatakan Romlah (2001: 3) bahwa bimbingan kelompok merupakan salah satu teknik bimbingan yang berusaha membantu individu agar dapat mencapai perkembangannya secara optimal sesuai dengan kemampuan, bakat, minat, serta nilai-nilai yang dianutnya dan dilaksanakan dalam situasi kelompok. Bimbingan kelompok ditujukan untuk mencagah timbulnya masalah pada siswa dan mengembangkan potensi siswa.

Usaha yang perlu dilakukan guna meningkatkan motivasi belajar adalah mengoptimalkan layanan bimbingan dan konseling kepada siswa. Salah satu kegiatan dalam bimbingan dan konseling yang akan dilaksanakan dalam rangka meningkatkan motivasi belajar adalah dengan bimbingan kelompok. Bimbingan membantu individu untuk lebih dapat mengembangkan diri secara optimal dengan jalan memahami diri, memahami lingkungan, mengatasi hambatan guna menentukan rencana masa depan yang lebih baik. Hal senada juga dikemukakan oleh Prayitno dan Erman Amti (2004), bimbingan adalah proses pemberian bantuan yang dilakukan oleh orang yang ahli kepada seseorang atau beberapa orang individu, baik anak-anak, remaja atau orang dewasa agar orang yang dibimbing dapat mengembangkan kemampuan dirinya sendiri dan mandiri dengan memanfaatkan kekuatan individu dan sarana yang ada dan dapat dikembangkan berdasarkan normanorma yang berlaku. Sementara Bimo Walgito (2004), mendefinisikan bahwa bimbingan adalah bantuan atau pertolongan yang diberikan kepada individu atau sekumpulan individu dalam menghindari atau mengatasi kesulitan-kesulitan hidupnya, agar individu dapat mencapai kesejahteraan dalam hidupnya. 
Menurut Johnson dan Johnson (dalam Romlah, 2001) kelompok adalah dua orang atau lebih individu yang berinteraksi secara tatap muka, masing-masing menyadari keanggotaannya dalam kelompok, mengetahui dengan pasti individu-individu lain yang menjadi anggota kelompok dan masing-masing menyadari saling ketergantungan yang positif dalam mencapai tujuan bersama. Menurut Tohirin (2007) bimbingan kelompok adalah suatu cara memberikan bantuan kepada individu atau siswa melalui kegiatan kelompok. Kelebihan dari bimbingan kelompok ini adalah dapat melatih siswa untuk hidup berkelompok dan menumbuhkan kerjasama antara siswa dalam mengatasi masalah, melatih siswa untuk mengemukakan pendapat dan menghargai pendapat orang lain dan dapat meningkatkan kemampuan siswa untuk dapat berkomunikasi dengan teman sebaya dan pembimbing (Winkel dan Sri Hastuti, 2004).

Berdasarkan pemaparan tersebut, dapat disimpulkan bahwa bimbingan kelompok memberikan kesempatan kepada siswa untuk belajar hal penting yang berguna untuk mengarahkan dirinya yang berkaitan dengan masalah pendidikan, pekerjaan, pribadi, dan sosial. Lebih lanjut, Tohirin (2007) mengatakan bahwa kegiatan kelompok dapat menjadi suatu teknik yang baik dalam bimbingan, karena kelompok dapat memberikan kesempatan pada individu (pada bakat dan menyalurkan dorongan-dorongan tertentu dan siswa dapat menyumbangkan pemikirannya. Dengan demikian muncul tanggung jawab dan rasa percaya diri. Hal ini didukung dengan hasil penelitian yang dilakukan Giyanti (2003) tentang meningkatkan motivasi belajar setelah mengikuti bimbingan kelompok motivasi belajar siswa kelas VII E SMP N 1 Getasan, dari hasil penelitan ini diperoleh $p=0,001<0,050$ artinya ada perbedaan yang signifikan antara kelompok eksperimen dan kelompok control setelah diberi bimbingan motivasi belajar. Riyanti (2000) tentang hubungan layanan bimbingan belajar dengan motivasi belajar siswa kelas XI SMA KRISTEN 1 Salatiga, dari hasil penelitian diperoleh ( $\mathrm{rxy}=0,365^{* *}$, $\mathrm{p}=0,000<0,001$ ). Artinya terbukti secara empirik ada koefisien korelasi sebesar 0,365 antara layanan bimbingan belajar dengan motivasi belajar. Teki Margawati (2007) tentang meningkatkan motivasi belajar melalui bimbingan kelompok siswa kelas VIIIB SMP N 3 Tuntang, dari hasil penelitian diperoleh $p=0,000<0,050$ artinya kegiatan layanan bimbingan kelompok berhasil meningkatkan motivasi belajar.

\section{SIMPULAN DAN SARAN}

\section{Simpulan}

Berdasarkan hasil analisis data yang telah diuraikan pada bab sebelumnya, maka penelitian ini menghasilkan kesimpulan: 1) Hasil penelitian menunjukkan bahwa kualitas motivasi belajar sebesar 48,79\%, dan bimbingan kelompok sebesar 71,96\%. Dengan demikian, dapat dikemukakan bahwa secara umum berada pada kategori yang cukup baik dan baik; dan 2) Berdasarkan hasil perhitungan diperoleh bahwa nilai signifikansi adalah 0,000 yang lebih kecil dari nilai $a=0,05$ dan nilai $r_{\text {hitung }}$ adalah $0,599^{* *}$ pada kategori "sedang". Harga koefisien tersebut selanjutnya diuji signifikansinya dengan membandingkan $\mathrm{r}_{\text {tabel }}$ untuk $\mathrm{n}=80$ pada taraf $5 \%$ maka $\mathrm{r}_{\text {tabel }}=0,220$, di mana nilai $\mathrm{r}_{\text {hitung }}>\mathrm{r}_{\text {tabel }}(0,599>0,220)$ dan nilai signifikansi yang diperoleh lebih kecil dari 0,05 . Dengan demikian, Ha diterima yaitu ada hubungan layanan bimbingan kelompok dengan Motivasi Belajar siswa kelas VIII SMP Negeri 5 Rambah Hilir Kabupaten Rokan Hulu Provinsi Riau. Sementara kontribusi layanan bimbingan kelompok dalam meningkatkan Motivasi Belajar siswa sebesar 35,88\%.

\section{Saran}

Berdasarkan simpulan yang diperoleh dalam penelitian yang penulis laksanakan bahwa antara bimbingan kelompok dengan kemampuan mengatasi minat belajar siswa ada hubungan yang positif dan signifikan. Pernyataan di atas mengandung pengertian bahwa bimbingan kelompok diperlukan meningkatkan kemampuan mengatasi motivasi belajar siswa SMP Negeri 5 Rambah Hilir. Dari hasil kenyataan tersebut di atas penulis ingin memberikan masukan yang berupa saran-saran sebagai berikut: 1) Bagi Siswa, hendaknya dapatmenumbuhkembangkan kemampuan untuk melakukan kegiatan yang baik, bekerjasama dan berhubungan baik melalui bimbingan kelompok dalam rangka meningkatkan kemampuan mengatasi minat belajar; 2) Bagi guru, hendaknya memberikan perhatian kepada para siswa yang mengalami minat belajar agar mampu mengatasinya dana bakat yang dimiliki siswa dapat berkembang secara optimal dan prestasi belajarnya meningkat; dan 3) Bagi orang Tua, hendaknya dapat membimbing anaknya dengan member motivasi dan perhatian yang cukup agar anak lebih giat belajar, sehingga anak mampu mengentaskan diri dari kesulitan belajar. Dengan demikian prestasi akan meningkat. 
112 Instructional Development Journal (IDJ), Vol. 1, No. 2, Desember 2018, Hal. 107-112

\section{DAFTAR RUJUKAN}

Dewa Ketut Sukardi. 2003. Manajemen Bimbingan dan Konseling di Sekolah. Jakarta : PT. Bumi Aksara.

Dimyati dan Mudjiono. 2000. Belajar dan Pembelajaran. Jakarta: Rineka Cipta.

Djamarah, Bahri. 2002. Psikologi Belajar. Jakarta: Rineka Cipta.

Hamzah B. Uno. 2008. Teori Motivasi dan Pengukurannya. Jakarta: Bumi Aksara.

Max Darsono, dkk. 2009. Belajar dan Pembelajaran. Semarang: IKIP Semarang Press.

Muhibbin Syah. 1996. Psikologi Pendidikan. Bandung: Remaja Rosda Karya.

Oemar Hamalik. 2002. Proses Belajar Mengajar. Jakarta: Bumi Aksara.

Prayitno. 2009. Layanan Bimbingan dan Konseling Kelompok (Dasar Dan Profil)” Jakarta: Ghalia Indonesia.

Sardiman. 2004. Interaksi dan Motifasi Belajar Mengajar. Jakarta: Rajawali Press.

Suciati,dkk. 2004. Belajar dan Pembelajaran 2. Jakarta: Universitas Terbuka.

Syaiful Sagala. 2010. Konsep dan Makna Pembelajaran. Bandung: Alfabeta.

Tatiek Romlah. 2001. Teori dan Praktek Bimbingan Kelompok. Malang: UNM.

Wina Sanjaya. 2007. Strategi Pembelajaran. Jakarta: Kencana. 